\title{
Surgical masks decontamination for reuse by members of the public: feasibility study and development of home-based methods
}

Cheok Hong, Mun ( $\square$ mcheokho@dso.org.sg)

DSO National Laboratories

Sook Lan, Tan

DSO National Laboratories

Soo Zeng Fiona, Phua

DSO National Laboratories

Wei Qi, Lim

DSO National Laboratories

Shyue Wei, Pang

DSO National Laboratories

Vidhya, Novem

DSO National Laboratories

Geraldine, Chee

DSO National Laboratories

Yi Hui Shermin, Soh

DSO National Laboratories

\section{Research Article}

Keywords: Surgical mask, Decontamination, Hydrogen peroxide, Bleach, UVC

Posted Date: September 9th, 2020

DOl: https://doi.org/10.21203/rs.3.rs-72875/v1

License: (c) (i) This work is licensed under a Creative Commons Attribution 4.0 International License.

Read Full License 


\section{Abstract}

This study aims to propose decontamination methods that are suitable for use by members of the public to cope with the shortage of surgical masks during the current COVID-19 pandemic. 3-ply surgical masks were subjected to different decontamination protocols (heat, chemical, ultraviolet irradiation) to assess their abilities to achieve at least 4-log reduction of two common respiratory pathogens, H1N1 Influenza A virus, a single-stranded RNA enveloped virus similar to SARS-CoV-2 and Staphylococcus aureus, a Grampositive bacterium that is more resistant to decontamination than single stranded RNA enveloped virus. Decontaminated surgical masks were assessed for differences in breathability, particle filtration efficiency and bacteria filtration efficiency as compared with non-decontaminated masks. The number of decontamination cycles that the 3-ply surgical masks could undergo without significant changes in breathability and filtration efficiencies were also determined. It was found that surgical masks decontaminated by either soaking for $60 \mathrm{~min}$ in $0.5 \%(\mathrm{v} / \mathrm{v})$ aqueous hydrogen peroxide solution, or 30 min of soaking in $0.05 \%-0.5 \%(\mathrm{v} / \mathrm{v})$ aqueous sodium hypochlorite diluted from household bleach or ultraviolet irradiation by a surface dose of $13.5 \mathrm{~kJ} / \mathrm{m}^{2}$ were able to achieve at least a 4-log reduction of both Staphylococcus aureus and H1N1 Influenza A virus spiked on surgical mask test swatches. No significant changes in breathability and filtration efficiencies of the surgical masks were observed after ten decontamination cycles of hydrogen peroxide or diluted bleach treatment or 30 cycles of ultraviolet irradiation.

\section{Introduction}

During outbreaks of acute infectious respiratory diseases such as the current coronavirus disease 2019 (COVID-19), transmission could occur through inhalation of infectious droplets expelled by COVID-19

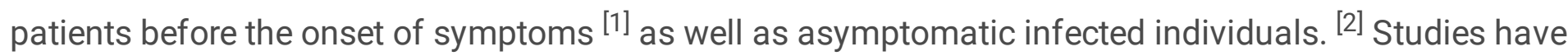
shown that viral copies expelled into the environment during exhalation are reduced by wearing a mask.

[3] This has led to a widespread public health recommendation to wear a mask in public to limit the spread of COVID-19. The competing need of masks by both medical and frontline workers, as well as the public, exacerbated by worldwide restrictions on the export of medical supplies, could result in temporal shortage in supply of surgical masks when it is most needed. ${ }^{[4]}$ Developing methods to ensure safe reuse of surgical masks by the public would help to reserve dwindling stock of fresh surgical masks for healthcare workers during such critical moments.

To allow for safe reuse of surgical masks that were designed for single use, it is essential to develop efficient and facile methods to remove microbial contaminants persisting on used masks without damaging the filtration properties of the mask. In particular, studies have indicated that $\sim 0.1 \%$ of the original inoculum of infectious coronavirus persists on the outer layer of a surgical mask seven day after contamination. ${ }^{[5]}$ To date, while there are many studies reporting on efficacy of various decontamination methods on N95 surgical masks, ${ }^{[6]-[12]}$ there is a paucity of decontamination studies to allow re-use of contaminated surgical masks by healthy individuals in public to abate the spread of COVID-19. 
Expanding on the research performed on reusing N95 filtering facepiece respirators, the goal of our study was to identify and propose accessible methods readily adoptable by the general public for decontaminating used surgical masks to allow for its safe re-use (single user reuse).

The decontamination methods were selected from similar studies performed on N95 respirators, ${ }^{[6]-[12]}$ as well as recommendations from the United States Centers for Disease Control and Prevention (CDC) ${ }^{[13]}$ and World Health Organization (WHO) for inactivating SARS-CoV-2 virus. ${ }^{[14]}$ Decontamination methods such as application of dry heat at $70^{\circ} \mathrm{C}$ for five minutes or heating at high humidity levels, ${ }^{[10]}$ chemical methods such as $70 \%$ ethanol, ${ }^{[10]}$ bleach ${ }^{[5]}$ and vaporized hydrogen peroxide, ${ }^{[10]}$ as well as UV-C irradiation ${ }^{[10]}$ were reported to be effective for inactivation of SARS-CoV-2. Since the target group is the public, the decontamination methods selected in this study explored techniques that could be readily carried out using household commodities and appliances. The methods included in our studies were steaming, immersion in hot water, boiling, soaking in different household disinfectants such as diluted bleach and aqueous hydrogen peroxide solution, $70 \%(\mathrm{v} / \mathrm{v})$ ethanol and liquid detergent. Irradiation using ultraviolet (UV-C) light was also investigated.

\section{Results}

\section{Differential pressure (delta-P), Particulate filtration efficiency (PFE) and Bacteria filtration efficiency (BFE) after decontamination}

A preliminary assessment on the feasibility of reusing surgical masks was carried out by comparing the PFEs before and after wearing the masks without prior decontamination. Wearing the masks for $8 \mathrm{~h}$ or more did not result in any significant change in the $\mathrm{PFE}_{0.1 \mu \mathrm{m}}$ and the trend in the $\mathrm{PFE}_{0.05-0.6 \mu \mathrm{m}}$ remained unaffected. This indicated that the PFE was retained in the worn mask and thus mask reuse could be feasible if the inactivation protocol of microbes does not alter the mask filtration properties.

Masks were subjected to heat, chemical and UV-C decontamination as listed in Table 1. Visual assessments performed on the decontaminated masks revealed no visible signs of damage. The melt blown filter layer of the untreated and treated masks were found to have no differences when viewed under the SEM. No chlorine off-gassing was detected on masks treated with bleach (Details are described in the supplementary information). The masks attained a metallic smell after UV-C decontamination, but this smell dissipated after airing for 15 minutes.

Effective decontamination methods should preserve the breathability of the masks. The delta-P of masks treated by all the methods in Table 1 were below $5.0 \mathrm{mmH}_{2} \mathrm{O} / \mathrm{cm}^{2}$, which indicated acceptable levels of breathability.

Prolonged duration of heating was found to degrade the filter layer. The PFE of masks treated by 30 mins boiling was significantly different from untreated masks (P-value=.0004). The PFEs $\mathrm{s}_{0.1 \mu \mathrm{m}}$ of surgical mask treated by steaming, hot water and boiling decreased as the duration of applied wet heat increased from 
10 to 30 minutes. The degradation of the masks was even more obvious when comparing $\mathrm{PFE}_{0.05-0.6 \mu \mathrm{m}}$ as shown by a decrease in PFE observed across this range of entire aerosol sizes (Figure 1). Even though it has been reported that $70^{\circ} \mathrm{C}$ for 5 minutes is adequate for inactivation of SARS-CoV-2, ${ }^{5}$ such precise temperature measurement and control is difficult to achieve in most households. Thus, heat inactivation of microbes may not be a practical repeated decontamination approach for households.

In addition, the surgical masks treated with $70 \%$ ethanol and detergent had noticeable change in the filtration efficiency. Although there was no significant difference in PFEs ${ }_{0.1 \mu \mathrm{m}}$ for masks treated by either $70 \%$ ethanol (P-value $=.08$ ) or dishwashing detergent (P-value=.04), the BFE of both detergent ( $\mathrm{P}$ value $=.002)$ and $70 \%$ ethanol (P-value $=.007)$ were significantly reduced from the value of untreated masks. Furthermore, PFEs ${ }_{0.05-0.6 \mu m}$ for these methods were observed to reduce by more than $40 \%$ from the untreated masks. These two methods were thus not pursued in subsequent investigations.

In comparison, 30 minutes of soaking in diluted bleach solution $(0.05-0.5 \%(\mathrm{v} / \mathrm{v}) ; \mathrm{pH}=11)$ or 60 minutes of soaking in $0.5 \%(\mathrm{v} / \mathrm{v})$ hydrogen peroxide solution $(\mathrm{pH}=5)$ or UV-C irradiation that delivered a surface dose of $13.5 \mathrm{~kJ} / \mathrm{m}^{2}$ pose minimal effects on the filtration properties of the surgical mask, as assessed respectively by $0.1 \mu \mathrm{m}$ polystyrene latex sphere $\left(\mathrm{PFE}_{0.1 \mu \mathrm{m}}\right)$, poly-dispersed aerosols of charge-neutralized bis(2-ethylhexyl) sebacate (DEHS) $\left(\mathrm{PFEs}_{0.05-0.6 \mu \mathrm{m}}\right.$ ) and $3 \mu \mathrm{m}$ bacteria aerosols (BFE; Table 1 and Figure 1). These methods of soaking in diluted bleach or hydrogen peroxide solution or UV-C exposure were also found to have minimal effects on the breathing resistance of the surgical mask. Hence, these methods were selected for antimicrobial studies to assess their decontamination effects.

\section{Antimicrobial efficacy test}

Antimicrobial studies could not be done on SARS-CoV-2 virus because BSL3 laboratory was inaccessible to the team. Instead, Influenza A subtype H1N1 virus, which is also a lipid enveloped single-stranded RNA virus and bacterium $S$. aureus were used in our investigations as they are common pathogenic microbes that causes respiratory diseases in the community. In addition, $S$. aureus, which is a type of vegetative bacteria that has been reported to be more resistant to inactivation by chemical and UV-C decontamination as compared to lipid enveloped viruses. ${ }^{[15]}$ By choosing these two microbes, the decontamination method would be applicable to the public for the current pandemic COVID-19.

All 3 decontamination methods, namely soaking in $0.5 \%(\mathrm{v} / \mathrm{v})$ hydrogen peroxide for 60 minutes or soaking in $0.05 \%(\mathrm{v} / \mathrm{v})$ sodium hypochlorite $(1 \% \mathrm{v} / \mathrm{v}$ bleach) for 30 minutes or UV-C irradiation using surface dose of $13.5 \mathrm{~kJ} / \mathrm{m}^{2}$ of UV-C, were found to achieve at least 4-log reduction for $S$. aureus bacteria and $\mathrm{H} 1 \mathrm{~N} 1$ virus (Table 2).

\section{Determination of number of decontamination cycles possible for each method}

Repeated cycles of the three decontamination methods were carried out to ascertain the maximum number of decontaminations that the 3-ply surgical mask could be subjected to without significant loss 
of barrier function or increased breathability. Our results showed that the breathing resistance (delta-P), PFEs and BFE of the masks did not change after being subjected to any of these 3 decontamination methods, namely ten cycles of hydrogen peroxide $(0.5 \% \mathrm{v} / \mathrm{v} ; 60 \mathrm{~min})$ decontamination, or ten cycles of bleach $(0.05 \% \mathrm{v} / \mathrm{v}$ and $0.5 \% \mathrm{v} / \mathrm{v}$ sodium hypochlorite; $30 \mathrm{~min})$ decontamination, or 30 cycles of 13.5 $\mathrm{kJ} / \mathrm{m}^{2} \mathrm{UV}-\mathrm{C}$ irradiation (Table 1).

\section{Discussion}

Studies by other researchers have demonstrated that a 5 minutes decontamination process with household bleach diluted up to 100 times was sufficient to kill SARS-CoV-2 (concentration of sodium hypochlorite was not reported). ${ }^{5}$ While we did not evaluated the anti-viral efficiency of diluted bleach for decontaminating surgical mask contaminated with SARS-CoV-2, the conditions evaluated in our bleach decontamination experiments $(0.5 \%$ and $0.05 \%$ sodium hypochlorite, representing 10 and 100 times dilution of household bleach respectively) should be sufficient to inactivate SARS-CoV-2 contaminants on the mask.

No study has been reported on the inactivation of SARS-CoV-2 using liquid hydrogen peroxide. A past study demonstrated that a concentration of $2.1 \%$ of hydrogen peroxide applied over 10 minutes (concentration $x$ time $=21 \%(\mathrm{v} / \mathrm{v})$. $\mathrm{min}$ ) could achieve a 4-log reduction of murine norovirus (a nonenveloped, single-stranded RNA virus) on surfaces. ${ }^{[17]}$ As non-enveloped virus are reported to be more resistant to chemical disinfectants than lipid enveloped virus, ${ }^{[15]}$ a concentration $x$ time value of $30 \%$ $(\mathrm{v} / \mathrm{v})$.min used in our hydrogen peroxide decontamination studies $\left(\mathrm{pH}=5,25\right.$ to $\left.35^{\circ} \mathrm{C}\right)$ is expected to achieve similar 4-log reduction of SARS-CoV-2 single-stranded RNA virus.

For UV-C light decontamination, we observed that irradiation on the surface of the mask achieved 5.49log reduction for $S$. aureus and 4.26-log reduction for H1N1 by applying a UV-C surface radiance exposure dose of $13.5 \mathrm{~kJ} / \mathrm{m}^{2}$. Attenuation of the light through the mask resulted in $9.2 \%$ of the UV-C light reaching the inner side of the masks to give a dose of $1.3 \mathrm{~kJ} / \mathrm{m}^{2}$ without flipping the mask during the irradiation process. To date, there is a paucity of peer-reviewed studies on the UV-C susceptibility of SARS-CoV-2

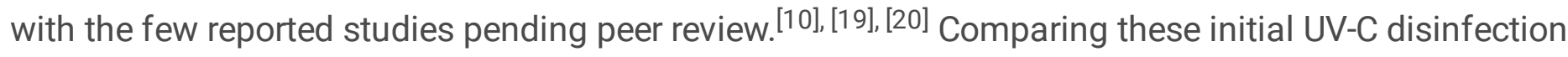
studies against SARS-CoV-2 virus with peer-reviewed data on UV-C susceptibilities of SARS-CoV-1 and other enveloped viruses with single-stranded RNA, ${ }^{[6],[18], ~[21] ~ a ~ l a r g e ~ v a r i a t i o n ~ i n ~ U V-C ~ d o s e ~ r e q u i r e d ~ f o r ~}$ inactivation of coronaviruses $\left(0.06 \mathrm{~kJ} / \mathrm{m}^{2}\right.$ for the bovine coronavirus to $117.54 \mathrm{~kJ} / \mathrm{m}^{2}$ for SARS-CoV- 1 , Urbani strain was observed. ${ }^{[21]}$

These extreme variations were reported to arise from variations in experimental conditions in these studies. ${ }^{[21]}$ Excluding variations caused by experimental conditions, coronaviruses were reported to be very sensitive to UV-C light, with an upper dose limit of $0.1 \mathrm{~kJ} / \mathrm{m}^{2}$ required for 1 -log inactivation. The 
corresponding dose required for 4-log inactivation of coronavirus was $0.42 \mathrm{~kJ} / \mathrm{m}^{2}$, which is three times lower than the measured UV-C radiance exposure transmitted through a typical 3-ply surgical mask ( 1.3 $\mathrm{kJ} / \mathrm{m}^{2}$ ). As SARS-CoV-2 virus does not differ structurally in any great extent from other known coronaviruses, they are expected to be similarly sensitive to the germicidal properties of UV-C radiation to produce 4-log reduction of these viruses trapped on the surface of a 3-ply surgical mask

More investigation will be needed to ascertain the UV-C dose to inactivate SARS-CoV-2 trapped within 3ply surgical mask since factors such as material, attenuation of the mask, or presence of interference like mucin and saliva from the user has to be taken into considerations.

\section{Materials And Methods}

\section{Materials}

The surgical mask used was a 3-ply ear loop model with a melt-blown polypropylene middle layer (SM3EP-50G, Arista Sensi, Indonesia). The $70 \%$ ethanol and $0.5 \%$ hydrogen peroxide without stabiliser solutions - semiconductor grade were obtained from Merck (Singapore) and a $3 \% \mathrm{H}_{2} \mathrm{O}_{2}$ antiseptic solution with stabiliser was obtained from ICM Pharma (Unity Pharmacy, Singapore). Investigation showed no impact on the mask filtration efficiencies between using the $0.5 \% \mathrm{H}_{2} \mathrm{O}_{2}$ solution prepared from the antiseptic solution versus the semiconductor grade $\mathrm{H}_{2} \mathrm{O}_{2}$ solution. Regular household dishwashing detergent based on linear alkylbenzene sulfonates was used for the testing (Mama Lemon, Lion Corporation, exact composition was unknown). A 5\% sodium hypochlorite household bleach (FairPrice Anti-Bacterial Bleach - White, Singapore) was used as the stock solution for the bleach treatment study. The UV-C treatment was carried out in a self-built UV cabinet, fitted with two $30 \mathrm{~W}$ low pressure germicidal lamp (G30T8, Sankyo Denki, Japan) with wavelength centred at $254 \mathrm{~nm}$. A radiometer with a UV-C probe (Delta OHM H2101.2 and LP471UVC probe, Italy) was used for measuring the UVC power density between 220 to $280 \mathrm{~nm}$ within the cabinet. Viral ToxGlo ${ }^{\mathrm{Tm}}$ Assay (Promega, USA) was used for the antiviral assays.

\section{Inactivation methods}

The treatment methods investigated include 1) heat treatment by boiling, immersing in hot water and steaming, 2) chemical treatment using hydrogen peroxide, bleach, ethanol and liquid detergent and 3) UV$\mathrm{C}$ treatment. Unless or otherwise stated, the experiments were conducted with the full surgical mask.

\section{Heat treatment}

The procedure for heat treatment by hot water was as follows. Water was heated using an electric kettle. The water was then transferred to a heat-insulated bowl immediately. The mask was fully submerged into the hot water $\left(80\right.$ to $90^{\circ} \mathrm{C}$ ), with weights to hold down the mask. The solution was covered to minimise cooling and left to stand for 10 and 30 min respectively. The temperature of water was found to be 40 to $45^{\circ} \mathrm{C}$ after $30 \mathrm{~min}$. 
The procedure for steaming was as follows. A metal steamer was placed inside a pot and water was filled to just below the bottom of the steamer. The water was brought to a boil. The mask was then placed on the metal steamer with the inner layer facing downwards. The masks were steamed for 10 and 30 min with the lid covered.

Boiling treatment was conducted as follows. Water was brought to a boil in a pot, after which, the mask was submerged inside the boiling water for 10 and $30 \mathrm{~min}$, with the lid of the pot covered.

After each respective heat treatment, the mask was left to dry at room temperature.

\section{Chemical treatment}

Procedures for bleach treatment were as follows. Store-bought bleach was diluted to give $0.05 \%$ sodium hypochlorite (bleach: water=1:99) and the mask was submerged fully for $30 \mathrm{~min}$. Similar procedure was carried out for $0.5 \%$ sodium hypochlorite solution (bleach: water $=1: 9$ ).

Steps for treatment by surfactant-based soap was as follows. Store-bought dishwashing detergent was diluted with water (final volume: $200 \mathrm{~mL}$, final concentration: $5 \mathrm{mg} / \mathrm{mL}$ ) and the mask was submerged fully for 1 minute.

Steps for hydrogen peroxide treatment was as follows. Mask was submerged fully in $0.3 \%$ hydrogen peroxide solution for $30 \mathrm{~min}$. Similar procedure was carried out with $0.5 \%$ hydrogen peroxide for 1 hour.

Steps for ethanol treatment was as follows. Mask was submerged fully in $70 \%$ ethanol $(200 \mathrm{~mL})$ for 10 min before removal.

After each respective chemical treatment, the mask was rinsed with tap water to remove the soaking chemicals and left to dry at room temperature.

\section{UV-C treatment}

Pre-determined locations with receiving power density of $10-15 \mathrm{~W} / \mathrm{m}^{2}$ was marked in the UV cabinet. The masks were placed at these locations and irradiated for $15 \mathrm{~min}$. The total mask was subjected to a surface dose of 9 to $13.5 \mathrm{~kJ} / \mathrm{m}^{2}$ during each cycle of irradiation. The amount of light that reached the bottom layer was approximately $9.2 \pm 0.3 \%$ of the total irradiated light, which is equivalent to a dose of $1.3 \mathrm{~kJ} / \mathrm{m}^{2}$.

\section{Off-gassing measurement of chlorine}

Measurement of possible off-gassing of chlorine were performed at two stages of the decontamination process: 1) immediately after rinsing of the surgical mask with tap water and 2) after drying of the surgical mask. A chlorine detector with a detection range of 0 to $1.5 \mathrm{ppm}$ with increment units of 0.01 ppm was used (Riken Keiki, SC-8000, Japan). No chlorine was detected when the air sampling probe was placed beside the mask at both stages. 


\section{Particle Filtration Efficiency (PFE) and Differential pressure (Delta-P) measurements}

The PFE was evaluated based on a modified test method stated in ASTM-F2299 standards. The aerosol filtration test rig system constructed using stainless steel was set up based on Scheme S1. The main deviation from the standard was using a smaller mask coupon of $9.6 \mathrm{~cm}^{2}$ and filtration efficiency was determined by measuring the aerosol concentration before and after insertion of the mask coupon using a single downstream aerosol isokinetic sampling probe.

A 6 port Collison nebuliser (BGI, USA) was used to generate the aerosols. The $0.1 \mu \mathrm{m}$ diameter polystyrene latex (PSL) beads solution prepared according to manufacturer instructions (Duke Scientific, USA) was used for the PFE testing, while a Di-Ethyl-Hexyl-Sebacat (DEHS) polydispersed aerosols was used to determine the filtration efficiency between 0.05 to $0.6 \mu \mathrm{m}$. The polydispersed DEHS has a geometric mean of $0.189 \mu \mathrm{m}$ and geometric standard deviation of 1.9. The aerosols were passed through a Krython-85 neutralizer (TSI Model 3012A) for the DEHS experiment and not in the PSL experiment. The aerosols were diluted by HEPA filtered laboratory air $\left(22 \pm 2{ }^{\circ} \mathrm{C}\right.$ with a humidity of $\left.65 \pm 10 \%\right)$ prior to entering into the test rig. All mask coupons were equilibrated in laboratory air environment and tested at a face velocity of $12.3 \mathrm{~cm} / \mathrm{s}$ controlled via a Mass Flow Controller (Dwyer, United States) in negative suction mode.

Concentration of PSL was measured by a condensation particle counter (TSI Model 3775) with the Differential Mobility Analyser (TSI Model 3081) electromobility diameter set at $0.11 \mu \mathrm{m}$. The DEHS concentration was measured in the scanning mobility particle sizer mode from 0.05 to $0.6 \mu \mathrm{m}$. Differential pressure across the mask coupons was measured using a micromanometer (TSI Model 5815).

\section{Bacterial Filtration Efficiency (BFE)}

BFE was conducted by an external vendor (TUV-SUV-PBS Pte Ltd). ASTM-F2101 test methods for evaluating BFE of medical face mask materials using biological aerosol of $S$. aureus was followed. The mean particle size of the challenge aerosol was $30.3 \mu \mathrm{m}$ over a flow rate of $28.30 .3 \mathrm{~L} / \mathrm{min}$ over a test area of approximately $38.5 \mathrm{~cm}^{2}$. The results of the untreated and treated mask samples were compared against negative control (filtered air) and positive control stream of $S$. aureus.

\section{Bacterial and Viral culture}

S. aureus (ATCC 25923), a Gram-positive bacterium found commonly in the upper respiratory tract, was used. It was cultured in tryptic soy broth (TSB) at $37^{\circ} \mathrm{C}$, overnight with shaking. $S$. aureus was diluted to 1 $x 10^{9}$ colony-forming units $\mathrm{CFU} / \mathrm{mL}$ using $1: 19$, TSB in $0.05 \%$ Triton $\mathrm{X}-100$ as the inoculating medium.

Influenza A/Puerto Rico/8/1934 (H1N1) was grown in embryonated chicken egg. The virus was harvested 3 days post-infection from the allantoic fluid. 


\section{Inoculation of biological agents on test swatch}

For anti-bacterial studies, $2 \times 10^{8} \mathrm{CFU}$ of $S$. aureus was inoculated onto square swatches $\left(16 \mathrm{~cm}^{2}\right)$ prepared from the surgical masks resulting. For anti-viral studies, $2 \times 10^{6}$ Plague Forming Unit (PFU) $\mathrm{H} 1 \mathrm{~N} 1$ in virus growth medium was inoculated onto square swatches $\left(1 \mathrm{~cm}^{2}\right)$. The inoculated swatches were allowed to dry at room temperature in a biosafety cabinet for $60 \mathrm{~min}$, before proceeding with the treatment studies.

\section{Treatment of the test swatch for anti-bacterial and anti-viral assays}

Briefly, for bleach treatment, the inoculated swatches were submerged fully in sodium hypochlorite solution $(0.05 \%$ and $0.5 \%)$ for $30 \mathrm{~min}$, followed by rinsing with deionised water thrice.

For hydrogen peroxide treatment, the inoculated swatches were submerged fully in $\mathrm{H}_{2} \mathrm{O}_{2}(0.3 \%$ and $0.5 \%)$ for $60 \mathrm{~min}$, followed by rinsing with deionised water thrice. The volume to surface area ratio was kept consistent at $0.4 \mathrm{~mL}$ solution (hydrogen peroxide or bleach) per centimetre square of test swatch.

For UV-C treatment, the inoculated swatches were placed at the pre-determined locations in the UV cabinet with the outer layer facing the UV lamp described in the earlier section.

\section{Anti-bacterial assays}

After treatment, the swatches were transferred to centrifuge tubes, and $10 \mathrm{~mL}$ of extraction buffer (TSB) was added, followed by vortexing for 1 minute. The supernatant was serially diluted, and plated in duplicates on tryptic soy agar (TSA) plates. The TSA plates were incubated for 24 hours before the CFUs on the plates were enumerated to determine the bacterial Log10 reduction for each treatment method, compared to the positive control (bacterial count extracted from inoculated swatches that were not inactivated).

\section{Anti-viral assays}

Viral growth medium (VGM) was added to the retrieved swatch and incubated at $37^{\circ} \mathrm{C}$, with shaking at $750 \mathrm{rpm}$, for 1 hour to extract any viable viral particles from the disinfected swatch. Half log serial dilutions of the extracted viral suspension were performed with VGM and added to Mardin-Darby Canine Kidney (MDCK) cells, and then incubated for 72 hours at $37^{\circ} \mathrm{C}, 5 \% \mathrm{CO}_{2}$. Viral ToxGlo ${ }^{\mathrm{TM}}$ Assay was used to detect viral cytopathic effects as per manufacturer's instructions. The amount of viable virus that caused $50 \%$ cell death in the MDCK cells (TCID50, tissue culture infectious dose) was inversely correlated to the measured luminescence, and the TCID50 value at 72 hours was calculated using the Reed and Muench method. The log reduction in viable virus for each inactivation method was determined by calculating the difference between the TCID50 of the respective disinfected swatch and the non-disinfected control swatch. Experimental results were representative of three independent experiments performed in triplicates. 


\section{Aging test}

The methods that were proven to retain the masks properties and attained sufficient log reduction for treatment were then selected for the aging test. Untreated masks were subjected to the hydrogen peroxide and bleach treatment for 10 times and UV treatment for 30 times respectively. The PFE and BFE results were then obtained and compared with the original value.

\section{Procedure for hydrogen peroxide and bleach decontamination}

The procedure for $0.5 \%$ hydrogen peroxide and $0.05 \%$ sodium hypochlorite (bleach) is shown in Figure $\mathrm{S} 1$. A $200 \mathrm{~mL}$ solution was sufficient for 4 masks. The masks should not be wring dry as this would cause some degradations to the mask, which affects their PFEs (Figure S2).

\section{Declarations}

\section{Acknowledgements}

We would like to thank DSO National Laboratories and Defence Science and Technology Agency for the funding support. We would also like to thank TÜV SÜD PSB Singapore for their bacterial filtration efficiency testing. We are also grateful to all the staff in Defence medical \& environmental research institute that render their help during the COVID-19 period. In particular, we would like to thank Dr Loke Weng Keong, Mr Kendrick Chew, Ms Loh Wai Leng and, Mr Jaya T B Jayaseelan for their assistance and advice rendered in the project.

\section{Additional information}

The authors declare no competing interests.

\section{References}

1. Zou, L. et al. SARS-CoV-2 viral load in upper respiratory specimens of infected patients. Engl. J. Med. Overseas Ed. 382, 1177-1179 (2020).

2. Bai, Y. et al. Presumed asymptomatic carrier transmission of COVID-19. 323, 1406-1407 (2020).

3. Leung, N. H. L. et al. Respiratory virus shedding in exhaled breath and efficacy of face masks. Med. 26, 676-680 (2020).

4. Chaib, F. Shortage of personal protective equipment endangering health workers worldwide. World Health Organization https://www.who.int/news-room/detail/03-03-2020-shortage-of-personalprotective-equipment-endangering-health-workers-worldwide (2020).

5. Chin, A. W. H. et al. Stability of SARS-CoV-2 in different environmental conditions. The Lancet Microbe. 1, e10 (2020).

6. Heimbuch, B. K. et al. Cleaning of filtering facepiece respirators contaminated with mucin and staphylococcus aureus. J. Infect. Control. 42, 265-270 (2014). 
7. Anderegg, L. et al. A scalable method of applying heat and humidity for decontamination of N95 respirators during the COVID-19 crisis. PLOS ONE 15, e0234851 (2020).

8. Cheng, V. C. C., Wong, S. C., Kwan, G. S. W., Hui, W.T. \& Yuen, K.Y. Disinfection of N95 respirators by ionized hydrogen peroxide in pandemic coronavirus disease 2019 (COVID-19) due to SARS-CoV-2. Hosp. Infect. 105, 358-359 (2020).

9. Kumar, A. et al. N95 mask decontamination using standard hospital sterilization technologies. Preprint at https://www.medrxiv.org/content/10.1101/2020.04.05.20049346v2 (2020).

10. Fischer, R. et al. Assessment of N95 respirator decontamination and re-use for SARS-CoV-2. Preprint at https://www.medrxiv.org/content/10.1101/2020.04.11.20062018v2 (2020).

11. Viscusi, D. J., Bergman, M. S., Eimer, B. C., Shaffer, R. E.. Evaluation of five decontamination methods for filtering facepiece respirators. Occup. Hyg. 53, 815-827 (2009).

12. Lindsley, W.G. et al. Effects of ultraviolet germicidal irradiation (uvgi) on N95 respirator filtration performance and structural integrity. Occup. Environ. Hyg. 12, 509-517 (2015).

13. Chemical disinfectants guideline for disinfection and sterilization in healthcare facilities. Centers for Disease Control and Prevention https://www.cdc.gov/infectioncontrol/guidelines/disinfection/index.html (2008).

14. Arduino, M. et al. Water, sanitation, hygiene, and waste management for the covid-19 virus. World Health Organization https://www.who.int/publications/i/item/water-sanitation-hygiene-and-wastemanagement-for-the-covid-19-virus-interim-guidance (2020).

15. Sattar, S. A. Hierarchy of susceptibility of viruses to environmental surface disinfectants: A predictor of activity against new and emerging viral pathogens. J AOAC Int. 90, 1655-1658 (2017).

16. Fisher, E. M., Noti, J. D., Lindsley, W. G., Blachere, F. M. \& Shaffer, R. E. Validation and application of models to predict facemask influenza contamination in healthcare settings. Risk Anal. 34, 1423-1434 (2014).

17. Li, D. et al. Inactivation of murine norovirus 1, coliphage phix 174, and bacteroides [corrected] fragilis phage b40-8 on surfaces and fresh-cut iceberg lettuce by hydrogen peroxide and uv light. Environ. Microbiol. 77, 1399-1404 (2011).

18. Mills, D., Harnish, D. A., Lawrence, C., Sandoval-Powers, M. \& Heimbuch, B. K. Ultraviolet germicidal irradiation of influenza-contaminated n95 filtering facepiece respirators. J. Infect. Control. 46, e49e55 (2018).

19. Bianco, A. et al. UV-C irradiation is highly effective in inactivating and inhibiting SARS-CoV-2 replication. Preprint at https://doi.org/10.1101/2020.06.05.20123463 (2020).

20. Inagaki, H., Saito, A., Sugiyama, H., Okabayashi, T. \& Fujimoto, S. Letter - Rapid inactivation of SARSCoV-2 with Deep-UV LED irradiation. Preprint at https://doi.org/10.1101/2020.06.06.138149 (2020).

21. Heßling, M., Hönes, K., Vatter, P. \& Lingenfelder, C. Ultraviolet irradiation doses for coronavirus inactivation - review and analysis of coronavirus photoinactivation studies. GMS Hyg. Infect. Contro/ 15, Doc08 (2020). 


\section{Tables}

Table 1. Summary of different decontamination methods, their delta-P, PFE, BFE. The P-value were obtained by two-tailed, unpaired Student's t-test with Welch's correction at 99\% confidence level. Triplicate measurements were conducted. 


\begin{tabular}{|c|c|c|c|c|c|c|}
\hline Decontamination & $\begin{array}{c}\text { No. } \\
\text { of } \\
\text { cycles }\end{array}$ & $\begin{array}{c}\text { Delta-Pa } \\
(\mathrm{mm} \\
\left.\mathrm{H}_{2} \mathrm{O} / \mathrm{cm}^{2}\right)\end{array}$ & $\begin{array}{c}\mathrm{BFE}^{\mathrm{b}} \\
(\%)\end{array}$ & $\begin{array}{c}\text { P-value of } \\
\text { BFE for } \\
\text { treated } \\
\text { masks }^{c}\end{array}$ & $\begin{array}{c}\mathrm{PFE}_{0.1} \\
\mathrm{~m}_{\mathrm{d}} \\
(\%)\end{array}$ & $\begin{array}{c}\text { P-value of } \\
\text { PFE }_{0.1 \mu m} \\
\text { for treated } \\
\text { masks }\end{array}$ \\
\hline $\begin{array}{l}\text { Criteria for } \\
\text { acceptance }\end{array}$ & & $<5.0$ & \multicolumn{4}{|c|}{$\begin{array}{l}\text { Student's t test, two tailed, 99\% confidence, } \\
\text { P-value }>.01\end{array}$} \\
\hline No decontamination & - & $2.2 \pm 0.1$ & $\begin{array}{l}99.7 \\
\pm 0.2\end{array}$ & - & $\begin{array}{l}93.2 \pm \\
1.5\end{array}$ & - \\
\hline Wearing for $>8$ hours & - & - & - & - & $\begin{array}{l}93.8 \pm \\
1.0\end{array}$ & 0.60 \\
\hline \multicolumn{7}{|c|}{ Chemical decontamination } \\
\hline Water (30 min) & 1 & $2.1 \pm 0.2$ & $\begin{array}{l}99.5 \\
\pm 0.1\end{array}$ & 0.22 & $\begin{array}{l}94.9 \pm \\
0.2\end{array}$ & 0.19 \\
\hline $\begin{array}{l}\text { Liquid detergent (1 } \\
\text { min) }\end{array}$ & 1 & $2.1 \pm 0.3$ & $\begin{array}{l}97.9 \\
\pm 0.3\end{array}$ & $0.002^{* *}$ & $\begin{array}{l}88.5 \pm \\
2.0\end{array}$ & $0.04^{*}$ \\
\hline $70 \%$ ethanol (10 min) & 1 & $\begin{array}{l}1.8 \pm \\
0.03\end{array}$ & $\begin{array}{l}98.8 \\
\pm 0.1\end{array}$ & $0.007 * *$ & $\begin{array}{l}90.6 \pm \\
0.6\end{array}$ & 0.08 \\
\hline \multirow{2}{*}{$\begin{array}{l}0.05 \% \text { sodium } \\
\text { hypochlorite ( } 1 \% \\
\text { bleach) (30 min) }\end{array}$} & 1 & $2.2 \pm 0.2$ & $\begin{array}{l}99.6 \\
\pm 0.1\end{array}$ & 0.50 & $\begin{array}{l}95.0 \pm \\
0.3\end{array}$ & 0.17 \\
\hline & 10 & $2.1 \pm 0.2$ & $\begin{array}{l}99.7 \\
\pm 0.1\end{array}$ & $>0.99$ & $\begin{array}{l}94.8 \pm \\
0.7\end{array}$ & 0.20 \\
\hline \multirow[t]{2}{*}{$\begin{array}{l}0.5 \% \text { sodium } \\
\text { hypochlorite (10\% } \\
\text { bleach) (30 min) }\end{array}$} & 1 & $2.1 \pm 0.2$ & $\begin{array}{l}99.7 \\
\pm \\
0.09\end{array}$ & $>0.99$ & $\begin{array}{l}94.8 \pm \\
0.7\end{array}$ & 0.20 \\
\hline & 10 & $\begin{array}{l}2.2 \pm \\
0.06\end{array}$ & $\begin{array}{l}99.7 \\
\pm \\
0.02\end{array}$ & $>0.99$ & $\begin{array}{l}92.1 \pm \\
1.6\end{array}$ & 0.43 \\
\hline \multicolumn{7}{|c|}{ Heating decontamination } \\
\hline Steaming $(10 \mathrm{~min})$ & 1 & $1.8 \pm 0.1$ & $\begin{array}{l}99.5 \\
\pm 0.2\end{array}$ & 0.29 & $\begin{array}{l}92.5 \pm \\
1.1\end{array}$ & 0.55 \\
\hline Steaming (30 min) & 1 & $1.9 \pm 0.3$ & $\begin{array}{l}99.7 \\
\pm 0.1\end{array}$ & $>0.99$ & $\begin{array}{l}90.5 \pm \\
2.7\end{array}$ & 0.22 \\
\hline Hot water (10 min) & 1 & $2.0 \pm 0.1$ & $\begin{array}{l}99.5 \\
\pm 0.2\end{array}$ & 0.29 & $\begin{array}{l}91.4 \pm \\
2.2\end{array}$ & 0.32 \\
\hline Hot water (30 min) & 1 & $1.8 \pm 0.2$ & $\begin{array}{l}99.0 \\
\pm 0.2\end{array}$ & $0.01 *$ & $\begin{array}{l}90.5 \pm \\
0.8\end{array}$ & 0.07 \\
\hline Boiling (10 min) & 1 & $1.9 \pm 0.3$ & $\begin{array}{l}97.3 \\
\pm 1.4 \\
\end{array}$ & 0.09 & $\begin{array}{l}91.8 \pm \\
0.9\end{array}$ & 0.25 \\
\hline Boiling (30 min) & 1 & $2.1 \pm 0.2$ & $\begin{array}{l}97.5 \\
\pm 1.2 \\
\end{array}$ & 0.08 & $\begin{array}{l}80.1 \pm \\
1.5\end{array}$ & $0.0004^{* * *}$ \\
\hline \multicolumn{7}{|c|}{ Hydrogen peroxide decontamination } \\
\hline $\begin{array}{l}0.3 \% \text { hydrogen } \\
\text { peroxide } \\
(30 \text { min) }\end{array}$ & 1 & $2.0 \pm 0.1$ & $\begin{array}{l}99.5 \\
\pm 0.3\end{array}$ & 0.40 & $\begin{array}{l}94.9 \pm \\
0.2\end{array}$ & 0.19 \\
\hline \multirow{2}{*}{$\begin{array}{l}0.5 \% \text { hydrogen } \\
\text { peroxide } \\
\text { (60 min) }\end{array}$} & 1 & $1.7 \pm 0.1$ & $\begin{array}{l}99.3 \\
\pm 0.2\end{array}$ & 0.07 & $\begin{array}{l}93.8 \pm \\
0.7\end{array}$ & 0.58 \\
\hline & 10 & $\begin{array}{l}1.9 \pm \\
0.08\end{array}$ & $\begin{array}{l}99.4 \\
\pm \\
0.05\end{array}$ & 0.11 & $\begin{array}{l}94.0 \pm \\
0.2\end{array}$ & 0.45 \\
\hline \multicolumn{7}{|l|}{ UV-C decontamination } \\
\hline $13.5 \mathrm{~kJ} / \mathrm{m}^{2} \mathrm{UV}-\mathrm{C}(15$ & 1 & $2.0 \pm 0.1$ & $\begin{array}{l}99.5 \\
\pm 0.3\end{array}$ & 0.40 & $\begin{array}{l}94.3 \pm \\
0.9\end{array}$ & 0.35 \\
\hline
\end{tabular}




\begin{tabular}{|l|l|l|l|l|l|l|}
\hline min) & 30 & $2.0 \pm 0.1$ & $\begin{array}{l}99.8 \\
\pm \\
0.04\end{array}$ & 0.48 & $\begin{array}{l}92.2 \pm \\
0.7\end{array}$ & 0.38 \\
\hline
\end{tabular}

a Delta-P $=$ differential pressure

$\mathrm{b}$ BFE = Bacterial filtration efficiency

C $(*)$ indicates p-value $\leq 0.05,(* *)$ indicates p-value $\leq 0.01(* * *)$ indicates p-value $\leq 0.001$

$\mathrm{d} \mathrm{PFE}_{0.1 \mu \mathrm{m}}=$ Particle filtration efficiency for particles of 0.1 micron

Table 2. Anti-bacterial and anti-viral data

\begin{tabular}{|c|c|c|c|}
\hline Target organism & Decontaminations & Time (min) & Log reduction \\
\hline \multirow[t]{5}{*}{ S. Aureus } & 0.05\% sodium hypochlorite & 30 & $6.60 \pm 0.05$ \\
\hline & 0.5\% sodium hypochlorite & 30 & $6.60 \pm 0.05$ \\
\hline & $0.3 \%$ hydrogen peroxide & 60 & $2.37 \pm 0.30$ \\
\hline & $0.5 \%$ hydrogen peroxide & 60 & $5.39 \pm 0.05$ \\
\hline & UV-C (Surface dose: $13.5 \mathrm{~kJ} / \mathrm{m}^{2}$ ) & - & $5.49 \pm 0.25$ \\
\hline \multirow[t]{5}{*}{ H1N1 } & $0.05 \%$ sodium hypochlorite & 30 & \multirow[t]{5}{*}{$4.62 \pm 0.13^{a}$} \\
\hline & 0.5\% sodium hypochlorite & 30 & \\
\hline & $0.3 \%$ hydrogen peroxide & 60 & \\
\hline & 0.5\% hydrogen peroxide & 60 & \\
\hline & UV-C (Surface dose: $13.5 \mathrm{~kJ} / \mathrm{m}^{2}$ ) & - & \\
\hline
\end{tabular}

a Due to the detection limit of the virus test kit, only up to 4.62-log reduction could be detected.

Figures 
Heat treatment
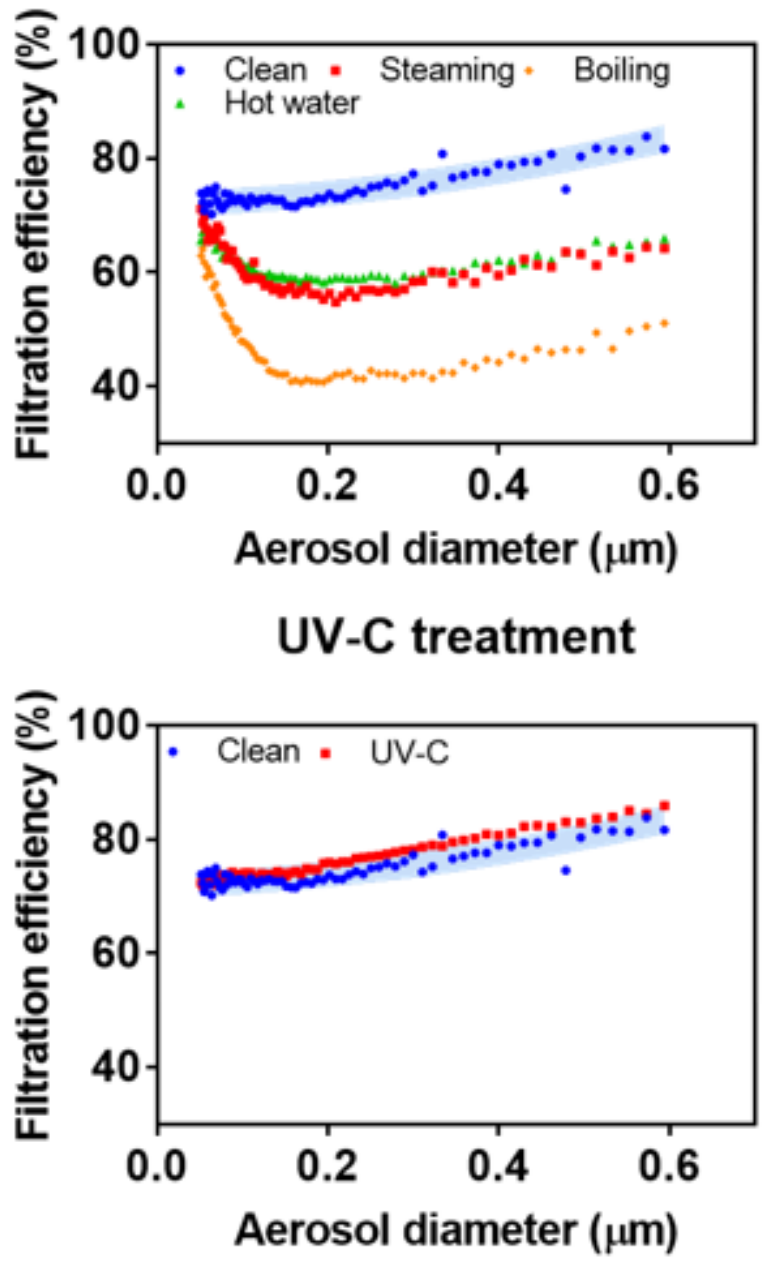

\section{Chemical treatment}

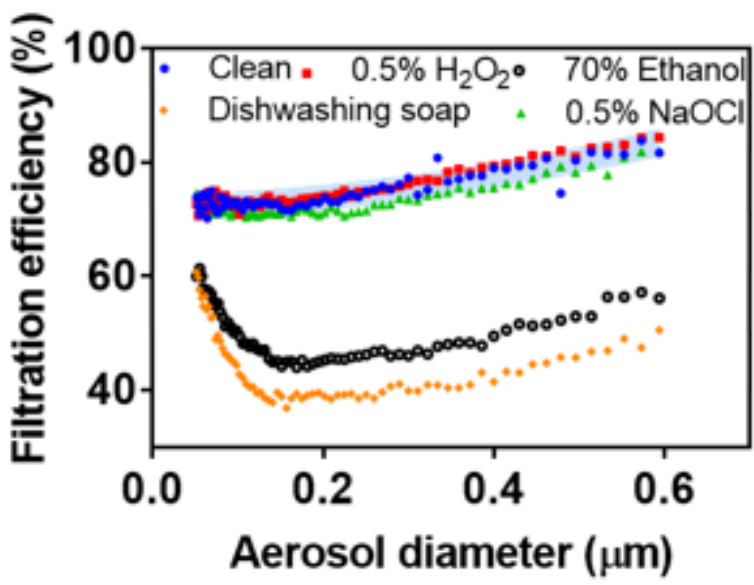

Aging samples

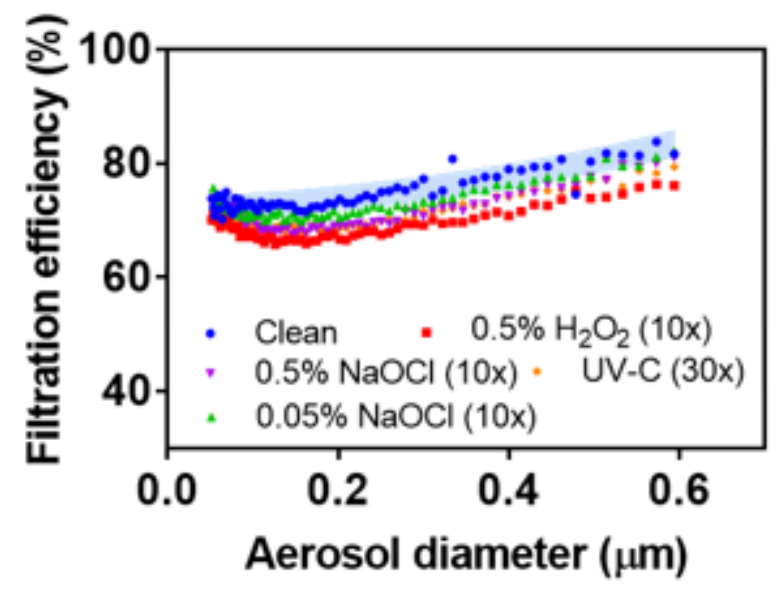

Figure 1

Plot of PFEs for different decontamination methods with different DEHS particle sizes of 0.05 to $0.6 \mu \mathrm{m}$. Data shown for heat decontamination are for samples exposed to $30 \mathrm{~min}$ of heat decontamination. The blue region indicates the prediction interval of the filtration efficiency of the clean mask at $90 \%$ confidence level. $\mathrm{H} 2 \mathrm{O} 2$ = hydrogen peroxide, $\mathrm{NaOCl}$ = sodium hypochlorite found in bleach

\section{Supplementary Files}

This is a list of supplementary files associated with this preprint. Click to download.

- FigS1.png

- FigS2.png

- SchemeS1.png 